\title{
Possible Reading through Syntagma of the Novel "Palace of Dreams" by Ismail Kadare
}

\author{
Edlira Çerkezi \\ $\mathrm{PhD}$, University “Ismail Qemali” Vlorë, \\ Department of Language and Literature
}

\begin{abstract}
One of the important issues of reading the novel "Palace of Dreams" is his reading, because of the metaphor that Kadare seeks to build with this kind of novel structure, with a very modern fiction, because of the overlap of times not according to events but according to situations, which help to discover Tabir Saraj, because of the movement of some symbols, to understand a kind of code, through which the novel must be understood, then for a complete reason related to time, like a black veil, which does not allow you to see the real face hiding behind it, also due to the absence of some characters, who in a classic romance structure carry or convey lines, situations, their classification and that stratify society .
\end{abstract}

Keywords: syntagma, novel, "Palace of Dreams", Ismail Kadare

\section{Introduction}

The "Palace of Dreams" is a difficult "journey" and difficult reading, as it is a conditional report at the time it was written. It is a timeless at a relatively early time and it is a generalizing metaphor, seeking to reveal a reality and a collective relationship, mainly in a labyrinth, where there are many streets, middle, floors, sub-floors, high numberless doors, people without names, except Mark - Alem, a stinking environment, which seems to be quite different from what is outside Tabir Saraj.

It is completely different from Tabir Saraji with the streets, people, houses, psychology, relationships, conditioning, obligations and freedoms, teahouses and saleptors, that are outside him. It is completely different in the house of Mark-Alem, except for the one who, from the first moment when he was "accepted" in Tabir Saraj, changed, lost the coordinates of his previous life and became one with the "Palace of Dreams", who carries and follows Mark Alem where he is and goes.

Always in the levels of reading and understanding of a literary work, of the type of "Palace...", "Pyramid", "Qorrfeman", and even the metaphor and parallel of "Broken April", the writer has had to communicate through forms, elements symbolic, and the most intelligent of literature. Ismail Kadare was probably "helped" by the conditions in which he wrote, to use masterfully and well that imaginary, archival material, in the wild or otherwise in creativity.

There are two times that are relatively far from each other in the "Palace of Dreams", an almost supernatural time, as if it were the syncretism of 1300 , for the psychology with which dreams 
are acquired in Tabir, and a time, almost the middle of past, when the novel was written. Ismail Kadare is known for using parables in such topics.

"Palace..." has a deep context to understand, it seems that there are two times; a real time and an unreal time. The actualization of the symbolism, which makes it function, to be alive and with a permanent present of the metaphor of the "Palace of Dreams", is not ready as in "The Great Winter","The General of the Dead Army", "Chronicle in Stone", except in the novel "Pyramid of Cheops, which seems to have a more obvious and more valorizing symbolism and to "Broken April", which transfers the events to rebuke and advise the present, despite the fact that for the latter there was a solidarity attitude of most critics and scholars, that the novel had a concern for a traditional savage and harsh experience, such as blood feuds, which at the time the novel was written did not work, which continues to be punishable to this day.

This in my opinion is the most obvious and most motivating part for the work to be published from the years 1970-1980.

\section{Metodology}

The novel "The Palace of Dreams is a tale of evil. In order for this story to be as present as possible, the author mostly mentions Tabir Saraj and less often the "Palace of Dreams", which, although not the same thing, complement each other. Thus the whole text reveals a sophisticated, constructed structure, especially because of the experience and real time, which does not appear, but is felt and is there in all the time, space, conjuncture and state conveyed by the book.

In this subject, of course, through a lot of difficult harvesting, through the correct perception of the word as a sign and as lexicology, of colored meanings, paradigms, incomplete sentences, emotional nuances, so the knowledge he has today for the word, it is revealed that the "Palace of Dreams" his inner shirt "Tabir Saraji" is a mysterious structure, a labyrinth, a structure that works through and with the absurd, a wiretapping structure, a mechanism nurtured and surviving by a ruling idea, an "institution" that works and has power from lack of facts, a hellish structure, an alienating place for man and the conscience of his, a structure that works with alibis, a "power" that through crime symbolism and fantasy produces crime.

In general, the novel "Palace of Dreams" has been difficult and problematic to read, due to the narrative structure and symbolism in which it is held.Being a structure transferred in time, one time within one time, the writer had to create projects of structures of social phenomena, experienced during the history of mankind, which had to communicate in the new temporal exchanges on the one hand, but also to respond to a development of aesthetic-social reasoning in time.

By designing a structure of totalitarianism, with an open influence overall social, geographical, mental, spiritual, human, ethnopsychic and other space, Kadare has built multiple structures, which materialize through textual and syntagmatic readings.

The novel "Palace of Dreams" is necessary to read in such a way to discover the idea of labyrinth, absurdity, mystery, hell, etc. Regarding this issue, in our work, in addition to the collection in the entire written text of the novel "Palace of Dreams" there is a classification of these structures for which there are numerous interferences, which complete one of the most important parts of the novel. 


\section{Results and discussion}

\section{Possible reading through syntagma}

The "Palace of Dreams" is a difficult "journey" and difficult reading, as it is a conditional report at the time it was written. It is a timeless at a relatively early time and is a general metaphor, seeking to reveal a reality and a collective relationship, mainly in a maze, where there are many streets, middle, floors, sub-floors, high numberless doors, people without names, except Mark - Alemi, a stinking environment, which seems to be quite different from what is outside Tabir Saraj.It is completely different from Tabir Saraji with the streets, people, houses, psychology, relationships, conditioning, obligations and freedoms, teahouses and saleptors, that are outside him. It is completely different in the house of Mark-Alem, except for the one who, from the first moment when he was "accepted" in Tabir Saraj, changed, lost the coordinates of his previous life and became one with the "Palace of Dreams", who carries and follows Mark -Alem where he is and goes.

Gjithmonë në nivelizimet e leximit dhe kuptimit të një vepre letrare, të llojit të "Pallatit...", "Piramidës", "Qorrfemanit", madje dhe të metaforës dhe paraleles së "Prillit të Thyer", shkrimtarit i është dashur komunikimi përmes formave dhe elementëve simbolik dhe më inteligjentët e letërsisë. Ismail Kadare ndoshta është "ndihmuar" nga kushtet në të cilat ai ka shkruar, për të përdorë mjeshtërisht dhe mirë atë lëndë imagjinare, arkivore, në kohë të egër apo ndryshe në krijimtari.

There are two times that are relatively far from each other in the "Palace of Dreams", an almost supernatural time, as if it were the syncretism of 1300 , for the psychology with which dreams are acquired in Tabir, and a time, almost the middle of the century past, when you wrote the novel. Ismail Kadare is known for using parables in such topics.

"Palace..." has a deep context to understand, it seems that there are two times; a real time and an unreal time. The actualization of the symbolism, which makes it function, to be alive and with a permanent present of the metaphor of the "Palace of Dreams", is not ready as in "The Great Winter", "The General of the Dead Army", "Chronicle in Stone", except in the novel "Pyramid of Cheops", which seems to have a more obvious and more valorizing symbolism and in "Broken April", who transfers the events to rebuke and advise the present, notwithstanding that for the latter there has been a solidary attitude of most critics and scholars, that that novel's a concern for a wild and harsh traditional experience, like the blood feud, which at the time you wrote the novel did not work, which continues to be punishable to this day.

This in my opinion is the most obvious and most motivating part for the work to be published from the years 1970-1980.

What happens in Tabir Saraj, that is, the "palace" occupies most of the novel, which means that the writer has been able to include all the "deeds" in his symbol. In the symbol palace, happen all that has happened in the experience of the cynical eavesdropping of humanity and what happens and in the real time of the novel.

The "Palace of Dreams" is a converting symbol, a symbol that seems to have gathered in its concentration many other elements of this symbol. All his space, despite appearing 'classified', labeled as "selection", "interpretation", "archive", all that space is almost anonymous, hostile and unidentified. Kadare has managed to bring it as he has imagined and known, as he has 
modeled and had knowledge about it, in many similarities and meeting points of actuality in which the writer has lived.

From the first step that Mark-Alem takes in Tabir Saraj, he faces a typical anonymity and envy to the point of cynicism. Nobody expects him, nobody looks at him and in a desert of steps, he is insecure. This situation and practice seems to be ongoing. The moment of rest, the saleptore and coffee buffet is full of people, while working time turns everything into a desert. What happens? Mark-Alem does not believe that there are so many people in this institution. Silent, hooded, cold, pale, distrustful in front of and with each other, everyone speaks in a low voice and eyes looking to the side, this army that enters and leaves Tabir, is never believed by MarkAlemi.

Tabiri is unknown to anyone, no matter how long he works in it, no matter how much you go through the central and peripheral middlelands, no matter how much you go through his alcoves. No one tells you to enter every door that knocks. Doors without numbers and without locks as the author says. In the long and desolate salons, washed and with a dim light betrays you and your step. The noise of the steps is de- valorized as a tide and ebb from one living room to another, from one floor to another. This is a strange kind of eavesdropping. Mark Alem never understood or learned where a sector begins and where it ends, where a Tabir floor begins and where it ends. Sudden, unexpected, anonymous, but careful - this is Tabir Saraji for Mark-Alem, who in a relatively short time, from autumn to spring reaches the top of the "Palace of Dreams". The moment he expects to fade, to be denigrated, to "drown", he rises. It arises for the irony of the pain and indefinite fate of the family. Kurti dies (sentenced to death), and his nephew Mark-Alemi is exalted. Paradox.

Tabiri remains the same, unknown and meaningless. Mark-Alemi could never know him, not the nooks and crannies, but also its essence and why the writer plays with the paradox, sometimes reminding us of "selection", sometimes "interpretation", sometimes both together as its essence, while a dream coming from the farthest reaches of the Asian continent or some province of Europe or the Balkans, strained it, made it a real hell for anyone who "cursed" the fatal dream on its way to the sovereign.

Paradox for an important clerk or a rule?! How impossible it is for Mark-Alem to find the "Archive", the underground floor, but in Tabir Saraj on all floors, alcoves, streets, corridors the light is the same. There is no sun. It stinks there. A heavy and impossible stench to disappear. With that kind of stench, mystery, cynicism, anonymity and silence starts from the first day of Mark-Alem and the novel and with it comes the beginning of spring (the last chapter of the novel) and the last information that comes to us through Mark -Alem in the novel and by Tabir Saraji.

For reasons, however fundamental, the "Palace of Dreams" has been and continues to pass through the multitude of opinions, studies, not infrequently and its counter-text.He in the apparent contrast of real time and with the typification and "authenticity" of a past time, placed as such between real time, the time of the writer and his real people, looks like an old boulder, thrown into a wide square, which people are afraid to approach, just as you are afraid to approach an old and dilapidated house, for fear that it may collapse at any moment.

Ismail Kadare has brought the "Palace of Dreams" as a written, semantic structure, poured into chapters and sub-chapters, paradigms and words, phrases and compositions - as a sophisticated text, but without forgetting to leave, even make "passwords" visible - in other 
words, semantic codes. Regardless of the means, despite the correlations of 'semiotic and semantic adventure', across the textual breadth, the small doors or windows through which you can penetrate Tabir are there.

"The perimeter" of the novel "Palace of Dreams", - which in the general assessment is his metaphor, and which as such, he, in addition to being considered a book with a typical finding on the topic he aspires, but also a bold book of citizen. The defining symbol, with which he has been appropriated all over the world, is savage, problematic and threatening to him, in particular. Despite the metaphor and valorizing geography, the novel was written in a small country like Albania, right in the heart of the Balkans and under a strict eavesdropping.

In the need to "decode" the whole structure and convergent symbolism of the novel "Palace of Dreams", language and its tools are combined, literary figuration, lexical attitudes and peculiarities, style, perception of time as reality and not as reality, state of mind, drawings of premises, constructions, few types and characters, historical dating, historical archives, images, imagination, assumptions, experiences from the past, cattle and models. Ismail Kadare has organized the most emblematic literature through this perception and creative practice.

The novel "Palace of Dreams" is more of a narrative than a meditation, although at first glance it seems more descriptive. It is a condensed, dense narrative with an obvious psychological subject, which is "planted" in a condensed, intelligent text, which must be known to be read.

But is the text of the novel "Palace of Dreams" a tool to discover "Tabiri Saraj" as a tool and "Palace of Dreams" as a symbol, as most of the time they are unified as a single, despite, I think they are not the same.

In the history of letters, the text lives long. Appreciation for the figuration and metaphor sought for it, symbolic references, and other eternal correlations change over time as the text is consistent and stubborn.The "Palace of Dreams" is never discovered, despite the fact that the writer Ismail Kadare puts the discovery of Tabir Saraj in the time of Mark-Alemi, an emblematic name, informative for the careful and intelligent reader, perhaps an extension of ancient Albanian times where the family comes from of him, not Abu Qerim (is not an essentially Islamized Albanian), and a marked adjective, a vi ( - ) in the middle, then an $\mathrm{Al}$, nistore, a sign (national symbol) of our times for the homeland of the Albanians ) and a suffix (-em), word-formation where the sign $\mathrm{Al}$.

In the first chapter "Breakfast", the second chapter "Selection", and especially in the third chapter "Interpretation", the narrative in the novel is condensed. Every moment and minute of time that passes seems to "produce" an event, a kind of "intimacy", a density, while in other chapters the romantic "event" seems to be laid out.

\section{Interpretation of the "Palace of Dreams" through syntagms and texture keywords}

The novel "The Palace of Dreams is a tale of evil. In order for this story to be as present as possible, the author mostly mentions Tabir Saraj and less often the "Palace of Dreams", which, although not the same thing, complement each other. Thus the whole text reveals a sophisticated, constructed structure, especially because of the experience and real time, which does not appear, but is felt and is there in all the time, space, conjuncture and state conveyed by the book.

In this subject, of course, through a lot of difficult harvesting, through the correct perception of the word as a sign and as lexicology, of colored meanings, paradigms, asindet (incomplete) 
sentences, emotional nuances, ie the knowledge that exists today for the word, it is revealed that the "Palace of Dreams" his inner shirt "Tabir Saraji" is a mysterious structure, a labyrinth, a structure that works through and with the absurd, a wiretapping structure, a mechanism nourished and surviving by a ruling idea , an "institution" that works and has power from lack of facts, a hellish structure, an alienating place for man and his conscience, a structure that works with alibis, a "power" that through symbolism and fantasy produces crime.

\section{Mystery}

Throughout the text there is a considerable number of words, styles, paradigms, wordsymbols, half-words, which reveal the mystery of the "Palace of Dreams". Specifically:

(Chapter "Breakfast") - at the mercy of anxiety (266), tried to remember (267), other side averages (268), the oracle of Delphi (272), the desert of the middle (276), the hall of the Cuckoos (279)), the real clerk of the mysterious palace (281), the Secret Tabernacle (287), the directorates that are duplicated (287),

(Chapter ("Selection") - the pain of gout (293), insomnia (297), because you are liked by us (299), enigmatic, smooth as a slab, where you have nowhere to cling (299), vengeful joy (300), the black cat (302), staring eyes (304), stinking salt (305), the most blind, the most fatal, ... the most state (312), to hear the silence (319),

(Chapter "Interpretation") - cynical enlightenment (362), everywhere was the same, silence and nothingness (328), old rainbow (332), dictionary table (333), thousands of shoes (337), blind chicken ( 337 . crazy star (351), like random sharks (354), disturbed light, undressed (358), zaten, sleep and death are the same thing (360), horses were frightened by their dreams (361) , trespassers (365),

(Chapter "Day of Rest") - a bad punctuality (368), miserable casket (368), the famous decree of "Qorrfeman", - (the state declared the blindness of tens of thousands of people), the sacrifice of the eyes (371), wax cascade (371), rare flower, cousin (374), ominous power (375), in times of crisis the power of Tabir Saraj either decreases or increases even more

(Chapter "Archive") - What it cost to put the head there - here, to show the places (382), exhaustion (382), clerk (or tabit, -or dream) (383), truly molise (385), Eh , dream world (387), ferment (387), rising of the dead (388), sleep of the mad (393), xanxa (388), trembling of impatience (402),

(Chapter "Dinner") - that depravity of imagination (411), like cuckoos of misfortune (422), dull pain (423), intermediate state (423), eyes were closing half over the other's sleep (425), dreams of false (430), happy conjectures, fear of superstitions (433), (Chapter "Spring Approach") - cunning proof (443), between the smile of politeness, always had a frozen point (446), had in his hands at night ( 447), fatal dream ... (447), had taken his uncle to the grave ... (447), and him to the post of director of Tabir (447), black sleep (453), terrible horror ( 453).

There is a total inability to recognize and navigate Tabir Saraj, almost ruthless, whether in the streets, doors, corridors, offices and sectors where you can knock and get information. It is also quite impossible to communicate and be informed about what is happening in this country, where an entire army seems to be working. Mark-Alem never learned where he is and where he is going, how he is working and how he should work, who should and can help him. He never learned who is more important and less important. He never learned when it 
was noon and when it was not, as the lights there are always the same and without any contact with other people's real time. What is sometimes called "intermediate state" accompanies the only mirror in which we can see Tabir Saraj-Mark Alemi inverted is from the first day of work until the last day.

This mystery, with a functional purpose is placed mostly on the psychological state and the time that Mark Alemi is in Tabir. He has in his hand, in a way, the fate of his family, one of the dreams that has passed through his hands, and that the symbolism and creative interpretation of Tabir, connects him with his family and exactly Kurti, that dream with a question mark from the hand of Mark-Alem, when he works in Selection he leads his uncle to the grave, while he ascends it to the top of Tabir.

\section{The idea of the labyrinth and the absurd}

In general, the novel "Palace of Dreams" has been difficult and problematic to read, due to the narrative structure and symbolism in which it is held. Being a structure transferred in time, one time within another, the writer had to create projects of structures of social phenomena, experienced throughout the history of mankind, which had to communicate in the new temporal exchanges on the one hand, but also to respond to a development of aesthetic-social reasoning in time. By designing a structure of totalitarianism, with an open influence overall social, geographical, mental, spiritual, human, ethnopsychic and other space, Kadare has built multiple structures, which materialize through textual and syntagmatic readings. The novel "Palace of Dreams" is necessary to read in such a way to discover the idea of labyrinth, absurdity, mystery, hell, etc. Regarding this issue, in our work, in addition to the coll ection in the entire written text of the novel "Palace of Dreams" there is a classification of these structures for which there are numerous interferences, which complete one of the most important parts of the novel.

\section{Labirint}

Tabir Saraj could not have been sophisticated, cruel, invincible and invincible, unknown and undiscovered, nor resistant to his atrocities, had it not been built as a labyrinth. It is impossible to learn about him how relationships are built between people, how middle roads communicate, how information comes and goes, and what entrances and exits are like. Where hides an entire army of employees, who communicate very little and not at all with each other.

(Chapter "Breakfast") - Middle (264), with dozens of high doors and without numbers (265), had the feeling that he was going down to the pantry (285),

(Chapter "Selection") - solid building (296), knitting tigers, the blind building (322), (Chapter "Interpretation") - in those rooms only the dreamers (339), the center idiot (346) are locked, suffocating the end of a breath (346), better in the cold field or in wolf forest than here. One hundred times better (357), (Chapter "Day of rest") - flake of light (365), from Tabir Saraji had not come out and no order could have come out (375), ...

(Chapter "Archive") - the archive is down, in the underground (381), it was spinning through its curves, without being able to find what it was looking for (382), it is a labyrinth where you can easily get lost (385), it was enough to leave this cavity, filled with files for understand what this world was like (386), ...

(Chapter "spring is approaching") - The fog continued to roll (440). 
Doors without numbers, salons for which we never learn what they illuminated with, you never learn on what floor of this building or structure, built me do not know what, Mark-Alemi himself works with, and with whom he is possible to "communicate" the reader and the writer. Somewhere the writer tells us "the blind edifice" and "solid building", an almost antonymous approach and relationship, with which we understand how confused the ways, communication and its acquaintances are. Somewhere in one of his moves, to go to the interpretation sector, Mark-Alem loses all orientation, as everything seems the same and unorientated, he thinks that he will search all day working and will not be able to to find neither a job nor be able to get out of this maze. He even thinks that he will probably spend the night in Tabir, as a "lost". For this reason, Tabir Sarajai is unknown, unexpected, unpredictable, and nonetheless impenetrable.

\section{Absurd}

The absurd, elevated to the norm, in principle of work and action is perhaps the mechanism that has made Tabir Saraj the longest-lived among the institutions of the Empire. Kafka's existential man is more liberated than Kadare's man, despite the fact that both are facing the "law", but for different reasons and reasons.

(Chapter "Breakfast") - I do not remember anything (265), the impression that he was listening to the continuation of a speech (272), millions and billions of other dreams (273), it is important to close Tabir Saraj from any external influence (274) ), his unusual name (277), Qiqrave Hell (279), preliminary peeling (279), but quite turbulent, as a legendary work (289),

("Selection" chapter) - the first signs of insomnia the state took action urgent (297), the insomnia of a people (297), the insomnia of man (297), enigmatic, smooth as a slab where you can not catch it (299), vengeful joy (300), the most blind, the most fatal , .. the most state (312), between the dragon and the serpent (315), they brought you an entire empire (317),

Chapter "Interpretation") - proclaimed the boredom of the world (368) musical instruments with the wasteland (347), the bridge with the musical instrument (347), the wasteland with the bull (347), could not completely forget his dream (348), malicious dream invented against the state (353), the Ottoman Empire ... bloody buildings, buried by time and then resurrected as ghosts (353), the horses with those files, it was known that they would not travel (361),

(Chapter "Rest Day") - proclaimed the boredom of the world (368), virgin imam 371), rebellion of conscience (301), rubbish, dust, broken pieces of ceramics, a raging bull, the foot of the bridge (301) , make a god dream (300), plumes of sleep clouds (377), eat with us, ... because he has the terrible power of lack of fact (375),

(Chapter "Archive") - dreams of captivity (388), the dreams of the first captivity (389), the dreams of the deep captivity (388), the files of the great nightmares (388), the dinner seemed to be standing somewhere upstairs, in another world, almost in the clouds (387), ...

(Chapter "The approach of spring") - did not remember anything (451).

It is probably one of the most difficult situations to understand and identify in the novel, for the simple reason, the absurd situations and rules in Tabir Saraj come sometimes as ruling perceptions, sometimes as eavesdropping tools, sometimes as mechanisms of alienation of the individual and sometimes as a violent structure and hell. Somewhere the author writes: "enigmatic, smooth like a tile, where you can not catch it ..." which means impossible to change, move it and even more so to use it. It is about the way the public is built in Tabir Saraj. 
While in another moment the author reveals this violent, murderous mechanism, specially invented to secure the rule, he writes: - "he could not completely forget his dream ...", a fate which has one of dreamers of a distant province, which does not constitute the devilishness of the dream, but reveals its devilishness as soon as it has entered Tabir Saraj. Part of the absurdity of principles, such as that of Tabir Saraj, has been and is the most used part of violent social and totalitarian systems, as the dream itself and the judgment of it in this way is a kind of absurdity, which has the historicism of itself and living in the body of totalitarianism.

\section{Textures, classifications}

Syntagmatic reading, which brings to stylistics a subject necessary to interpret deeply and consistently we used a written text, in this study, to bring a necessary opinion, regarding a proper approach to analytical reading and stable of the novel "The Palace of Dreams". The text is one of the important and enduring reflections to interpret and classify a literary work on a basic basis. Writing is one of the real possibilities of sustainability for a given work. She, the work, when written, actually begins her life, her journey. There is no future for a certain work outside the text. For the linguistic and textual tools that Kadare has used in his work "Palace of Dreams" is very important a kind of classification of semantic centers that he builds in the novel, because of the wide symbolic medium that the novel has.

\section{Tapping}

The first moment of Mark-Alem, which the writer introduces to us through a paradigm: "another man's eyes ..." is about eavesdropping. The experience of eavesdropping has a zoological basis, but to humans it does not seem to have been transmitted by animals, it was created by rulers. Eavesdropping is one of the most deadly "weapons" on innocent people, who confront their ruler, through mechanisms built specifically for this. Eavesdropping on Tabir Saraj sophisticated, an unwritten rule, but it works all the time.

(Chapter "Morning") - The eyes of another man (270), Tabir Total (273), like a lost spark (274), was orderly and threatening (276), (Chapter "Selection") - dreams were always seen and dreams were always sent (292), the ends of the state were endless (293), the first signs of insomnia, the state took urgent measures (297), an old misunderstanding (317),

(Chapter "Interpretation") - all doubts were wrapped (324)), secret extraction (325), interpretation ... creative work (327), you saw the moon inside and outside (333), watch out for this snake (335), evenly spaced (342), dragging the clocks (345), pedestrian dreamers (363),

(Chapter "Day of Rest") - As if most of what he had to say and swallow for himself (372), secret communications (374), dreams had now turned into some snakes to bite 375),

(Chapter "Archive") - Gloomy peoples (387), open peoples (387), in the alcove of the companion (companions), (390), those of the captivity of deep power (393), started towards him the stream of an icy smile (400),

(Chapter "Dinner") - Between the bridge of the rabid bull (427), the sun has rain and the rain has sun (432), (Chapter "The approach of spring") - the festive shadow (444), the cunning test (443), the insomnia of Albania (449),

Tabir Saraji manages to make a total eavesdropping, an all-imperial eavesdropping, a eavesdropping of several peoples and several languages. In addition, he accomplished this 
through a natural means, a means that passed the skirt of all people on summer and winter nights, on the edge of the bed, when they were healthy and sick, when they were married or unmarried. Sleep and dreams were the best opportunity to achieve this.

If the dreams were rare, in the mechanism of interception of Tabir Saraj something essential was missing, the raw material was missing. Somewhere the writer notes - "dreams were always seen and dreams were always sent ...", and this was enough for the structure of Tabir and the "Palace" to work, to have an opportunity to provide the Sovereign with Friday's dream, but when the "first signs of insomnia appeared, the state took urgent measures ..." the state lacked security. He thought someone was working against him. So the people had to sleep, sleep, dream and bring dreams to Tabir Saraj, to eat their head like the cabbage seller in a lost province of the empire, who you became the victim of his dream, first why he saw it and then why he could not forget it completely, because that is what Tabir and the "Palace ..." needed.

\section{Rule}

In the text of the novel, the words through which a ruling psychology is revealed piece-bypiece is more numerous than all other morphological and syntactic subjects are. A subject extends almost throughout the text and to a greater density than all the other issues assessed in the text of this book. The term rule occupies a large and interfering relationship with all the other specific terms in the book. After all, all the mechanisms that the writer manages to make the object of reflection in the book, bringing us Tabir Saraj, the model and the typical symbol of rule, serve this tool. Almost all stylistic tools, language, words, styles, which specifically have such a role in the text, serve and constitute the subject that reflects this historical phenomenon.

(Chapter "Breakfast") - the desire to leave evidence (266), the head of the terrible official (269), the recommendation is contrary to Tabir Saraj (271), founding institution (272), Tabir Totali (273), but a from the basics of the state (274), somewhere an old speech and they had divided among themselves like hyenas (278), interpretation is the essence of Tabir Saraj (287),

(Chapter "Selection") - thousands of branches of Tabir Saraj (294) ), domestic policy security (298), state security (298), foreign policy (298), Tabir Saraji has completely taken over the former shadow (312), you bring an entire empire (317), it you surrendered with savagery, even with blood (317), to share power with someone ... to share crimes (318), vengeful joy (300),

(Chapter "Interpretation") - Interpretation ... creative work (327), type of imprisonment (341), brainwashing, what a dream, madness, mind (342), threatening black streaks (342), s' had been able to completely forget his dream (348), eater and people (348), total time (352), dead states (352), I saw the state of Timur (353), the state of Herod (353), the sole of State (360),

(Chapter "Day of Rest") - No order had ever been issued by Tabir Saraji (375),

(Chapter "Archive") -Prostitutes with tired sex (366), it is not said in vain, recently, who has in his hand the "Palace of Dreams" has the keys to the state (373), the question is which world rules the other (376), we will look at the dreams of the sovereigns (392), when the Sovereign by special decree, has ceased to take into account the dreams (399), 
(Chapter "Dinner") - it was said that the Sovereign has turned back yesterday's dream (406), releasing the dream straight into it, fresh, like a newly laid egg (425), whore cursing the dream itself (435), say half of the dreamers have been arrested (436), the rings have fallen, but the fingers are (437),

(Chapter "The approach of spring") - the festive shadow (444), the fatal dream (447), had in his hand the night (447), as then he saw a coffin (450), the Cypriots had changed their surname to avoid, so recognition from the bridge (452).

The writer reveals this dimension in several planes and perspectives: first he introduces us to a vertical view of what the ruling concept has been since the Ottoman Empire to bring it through when the word state, founding institution, state floor, sovereign, decree, etc. is mentioned. .

Somewhere in Tabir's heart is the institution of interpretation (interpretation is the essence of Tabir Saraj), which provides him with the intelligence where he can and should act, strike, shine and issue curses and death. Totalitarianism and the mechanisms and means of domination seek and do their best to remain outside the crime they commit. In the chapter "Day of Rest", the author writes: "... no order had come out of Tabir Sarai and no order could ever come out ..." which means to wash your hands like Pilate after the crime. After all, the whole triumph of eavesdropping, of intelligence, of Tabir Saraj's essential and most important issue was interpretation. In Tabir, this sector was called its hierarchy.

Set in the conditions of historicism and metaphor of the novel "Palace of Dreams", mainly totalitarianism, which at the time of writing the novel required a broad geographical view, was interpreted through the ideological spirit, which did not always involve itself in the violence that exercised the state it governed and its mechanisms. Albania, the country of the writer has been a typical country of this mechanism.

\section{The terrible power of the factual lack}

"He eats with us," he continued slowly, "because he has the terrible power of lack of fact ..." , are the words of a man from the hierarchy of the Greatest Empire of the time, (Vizier of a province of the Empire), the only one one of whom we hear an almost direct consideration, which shows that Tabir Saraji has the terrible power to act with a lack of facts.

(Chapter "Breakfast") - sedative for anxiety (266), desire to leave evidence (266), in Tabir Saraj no recommendations are accepted (271), not penetration, but isolation, so not recommendation, but non-recommendation (271), pearl between a desert (274), the closure of Tabir Saraj to any external influence is important (274),

(Chapter "Selection") - Eyes in the distance (295), dark part of conscience (313), an old misunderstanding (317), to share power with someone, to share crimes (318),

(Chapter "Interpretation") - wrapped in all sorts of doubts (324), interpretation ... creative work (327), difficult interpretation (371), dotted snake- with the pillar, smoke, bride, slugs, snow (331), blind man (340), Anxieties of the Dead (344),

(Chapter "Day of Rest") - eat with us, - continued slowly, because he has the terrible power of lack of fact (375), from Tabir Saraji had not come out and no order could ever come out (375) , ominous power (375), the dreamers had now turned into some biting vipers (375), 
(Chapter "Archive") - gloomy peoples (387), open peoples (387), sleep of the mad (393), their order in the sentence was unnatural, like a crab movement (394), (Chapter Dinner ") - like cuckoos of misfortune (423), intermediate state (423), (Chapter" The approach of spring ") the fog continued to roll (440), cunning test (443), black sleep (453).

The lack of facts is an essential issue of the novel, which has a well-known historical valorization, which up to this point comes as an experience to survive such ruling structures as Tabir Saraji, Tabir Totali. Tabiri is not direct. The symbolism of the dream here is the essential and most important issue.

Tabir's brain, which is considered interpretation, through the writer's language is called "interpretation creative work", "difficult interpretation", and then all this is accompanied by a considerable amount of dream symbols, mainly the dotted snake the pillar, the smoke, the bride and the slugs, the snow "," the man of nothing ", " the anxieties of the dead ", or" the gloomy peoples, the open peoples, the sleep of the mad, unnatural, like a crab movement.

Kurt is killed by the alibis of the dream, which passed through the hands of his nephew MarkAlem. That big question mark, considered unbreakable, in the cold hall, with that killer white light like the shrouds of the dead, of interpretation, and the big question mark has been the fatal moment of the Cypriot family and in recent times. This was a lack of fact, but for Tabir it was a cruel power. It was enough for him to doubt, it was enough for the "creative" work of interpretation to consider such a symbolism that the dream brought to him, and the lack of fact, only aggravated and demonized the punishment and punishment even more.

\section{Hell}

It is almost a classic atmosphere atmosphere in Tabir Saraj. Dim and patched light, silent, sullen, frightened people who are afraid and look at each other with suspicion even in coffee, pale people, a mass like porridge and shapeless and shapeless is a hell of a structure. However, nothing passes without seeing each other, every alcove and pantry of Tabir Saraj is populated by the army of his employees.

The typical metonymy of Tabir Saraj, masterfully used by the writer, Tabiri for the Empire, insideTabiri- for outsideTabiri, is easy to understand how cruel is that "Palace of Dreams" in the whole space of the Empire and in the reality outside Tabir that in an somehow comes through the dreams that come to Tabir.

(Chapter "Breakfast") - Middle (264), with dozens (high) and without numbers (265), other side secondary (268), (Chapter "Selection") - you kept your mouth shut (294), their feet trembled (294), vengeful joy (300), review (300), staring eyes (304), like the fear of hell (304), make a god of dreams (310), knitting tigers, blind edifice (322),

(Chapter "Interpretation") - frozen by anxiety (325), daily life - perversion (330), care this snake (335), kind of imprisonment (341), brainwashing, ... center, madness, mind (342), black and threatening splashes (342), the hours dragged on (345), the description of hell (352) was occupied, better in the cold field or in the wolf forest than here ... dinner of cowherds (345), sore throat (346), the convicts cried (346), the unfortunate dreamer (348), the monster (348),(357),

(Chapter "Day of Rest") - the famous decree of "Qorrfeman", (the state declared the blindness of tens of thousands of people), the sacrifice of the eyes (371), the waterfall of wax (379), 
ominous power (375), time of irritation (376), the question is which world rules the other (376),

(Chapter "Archive") - truly creeping (385), the threshold of tears (387), the resurrection of the dead (388), life or death (388), trembling impatience (402), (Chapter "Dinner") - as a long complaint (411), the cavity of the soul (412), this cobra (421), tiger claw (427), wrong decomposition (431), (Chapter The approach of spring ") - terrible horror (453),

From the first day that Mark-Alem enters Tabir, something has broken inside him, which deepens day by day. In hell people are not together, they are held together by crime. In a hellish structure the dead "live" and not the living, they cannot talk to each other. The ferocious symbol, which is perceived to bring details, for a more correct understanding with Tabir Saraj, is hypothetical. In Tabir the living work, the dead come and go, so the dead live.

The irony and grotesque of the writer in this case is correct. In Tabir are the dark times of mankind, animals, sleep, dreams, those who collect dreams, those who bring them, are the sleep of gloomy peoples (rebellious peoples), are the dead and those who must die, the sins of sleep, are gloomy servants who are afraid to speak to each other, ie like the dead, because they "see each other's eyes" in every case.In Tabir no one answers you, nothing guides you, it is like in a deafness, in a place of the dead, where there is no longer any noise, where no one makes a sound.

However, precisely because of this silence, lack of noise, he is more abrupt and crueler. The quieter he is the crueler he actually is. He can instantly make the "famous decree of" Qorrfeman "(the state declared the blindness of tens of thousands of people), the sacrifice of the eyes", so that he can show his power and everyone can obey him.

\section{Alienation}

Why does Tabir Saraji alienate his people? Are his people, those who make up his army, who "protect" him, "give him life", "populate him", are his "organism", and are his "lungs" alienated people, as soon as they enter in Tabir Saraj? However, why is the alienation of the newly employed in Tabir intended and how is it realized? - "everywhere was the same thing - silence and nothingness", - it is noted in a moment of one of the employees of Tabir Saraj. It is the moment when Mark-Alem employed in the interpretation, the heart and the brain of Tabir Saraj.

The writer through such an elementation of the relationship of his people with Tabiri, with the "Palace of Dreams", seeks to discover in detail this structure with ancient experience, unfortunately capable of building such a fabrication and in recent times. It is a masterpiece of the author, who uses refractions to reflect what he needs.

(Chapter "Breakfast") - Their conversation cursed (264), terrified (265), I do not remember anything (265), sedative for anxiety (266), at the mercy of anxiety (266), was orderly and threatening (276), his unusual name (277),

(Chapter "Selection") - the whole cycle of work (297), the rebellion of conscience (301), to listen to silence (319), (Chapter "Interpretation") - numb from anxiety (325), cynical enlightenment (326), everywhere was the same - silence and nothingness (328), daily life perversion (330), wretched man (340), anxiety tightening (342), hours dragged on (345), 
(Chapter "Day of Rest") - Where time, the arm of things and everything else went completely differently (375),

(Chapter "Archive") - spun through its curves, not finding what it was looking for (382), really creepy (385), their order in the sentence was unnatural, like a crab movement (394),

(Chapter "Dinner") - The Vizier's eyes had something in common with broken glass, scattered throughout the room (419), mediocre state (423), and happy conjectures - fear of superstition (433),

(Chapter" The approach of spring ") - to play with him like a cat with a mouse (444), between the smile of politeness there was always a frozen point (446), the post of Chief of Bashëndërra (445), instead of the word "Albania", wrote "There" (451),

In no case has the writer in the premises of Tabir Saraj informed us about violence, clashes, outbursts, or open conflict. Everyone is silent; everyone works part-time and so silently leaves comes again tomorrow and so on. Violence, the case of the dreamer, who failed completely forget his dream, is only reported, and he is not an employee of Tabir.

In Tabir there is a strategy, an infection, a disease, an epidemic, the tools with which it works. Dealing with sleep and dreams, dealing with the symbolism that dreams bring and being forced to place them somewhere, in a real event, in a ruling structure to eavesdrop on their own people is embarrassing, torturous, difficult and alienating. It says "I do not remember anything", "soothing for anxieties", "at the mercy of anxiety", "he was orderly and threatening", "his unusual name", or "everywhere was the same thing - silence and nothingness", " daily life - perversion "," man of nothing "," anxiety ", so in Tabir we do not talk about man, but other things, about dreams and symbols, about diseases and vices, about doubts and traps, about animals sick and nothing, for intermediate states, which alienate you.

\section{Alibis}

The dominant histories in human experience are based on the construction of a mechanism that works with alibis. It is a tool used, through which the mass of "guilty" people is increased, the authority of the structure and institution is increased, fear and panic are demonstrated, and the opportunity to legislate is increased, to demonize the "legitimacy" of this rule, which is absurd. In Tabir this practice has a vertical effect and demonstration, from top to bottom. Somewhere the writer writes: - "maliciously invented dream against the state", "like that dish with hot peppers", "such a devilish dream", are all alibis, produced by Tabir Saraji.

(Chapter "Breakfast") - their cursed conversation (264), murmured without moving (268), questioning manner (267), another man's eyes (270), the impression that he was listening to the continuation of a speech (272), The Oracle of Delphi (272), preliminary peeling (279), selection, interpretation, The Secret Tabernacle (287), but quite turbulent, as a legendary work (289),

(Chapter "Selection") - Such old wolves (293), gout pain (293), insomnia (297), insomnia of a people (297), human insomnia (297), review (300), rebellion of consciousness (301), the dark part of consciousness (313),

(Chapter "Interpretation") - Cynical enlightenment (326), the shattering of dreams (327), important messages (334), thousands of shoes (337), blind chicken (337), this chin and this frost (343), bull enraged (347), unfortunate dreamer (348), nightmare (351), Pashallëku of 
Central Albania (352), maliciously invented dream against the state (353), like that dish with hot peppers (359), such a devilish dream (362),

(Chapter "Day of Rest") - a bad punctuality (368), miserable kasnec (368), as if most of what he had to speak and swallow for himself (372), in times of crisis the power of Tabir Sarajit either falls, or adds even more (376),

(Chapter "Archive) - exhaustion (382), all were stuffed (383), it was enough to leave this cavity, filled with files to understand what this world has been (386), the end of the world (387), the dreams of captivity (388), the changing mystery of the Battle of Kosovo (391), the dreams of the Kaur peoples (393), the dreams of deep captivity (388), the sleep of the mad (393) ,

(Chapter "Dinner") - that depravity of imagination (411), as a long complaint (411), dusty ground (413), between the bridge and the raging bull (427), which has something to do with an epic (427), Cypriots - (bridge) - epic (musical instrument) - against the state (rabid bull) (428), deep and deep wells (438), (Chapter "The approach of spring) - to play with him like a cat with mouse (444), cunning test (443), the words "appointment", "poor health" (445), fatal dream (447),

It is probably the most delicate and important structure of Tabir Saraji, the one that works with alibis, interpretation, the connecting point of all the information, readiness and relationship that Tabir Saraji has with the Sovereign, who every Friday announces and celebrates the dream. The symbolism of the dream (the flower as the author says), is one of the foundations of Tabir Saraj, in a way it is the orientation of the state. The fate of Kurt Qyprilliu best explains this: "The Cypriots - (bridge) - epic (musical instrument) - against the state (rabid bull) ..."

\section{Crime}

Consequently, the silent Tabir produces crime. It is a mechanism, built such, firstly as a potential possibility of evil, secondly in a violent experience of the human mind capable of constructing mechanisms and extensions of dark times, which have severely damaged life Human's. There is no more insidious death than that of Kurt, which complicates one of the most famous families in the history of the Empire. The Cypriots have been its founders and leaders for a long time and in its many difficult campaigns. After the execution of Kurti, MarkAlem almost takes the direction of Tabir Saraj. To be a reward for the "crime", which flowed from the hands and the inability of Mark Alem to scare the dream, with the bull, the violin, the bridge, the wasteland? Maybe! History of dictatorships!

(The chapter "Breakfast" - mediocre (264), terrified (265), other mediocre (268), the fates of states and rulers (272), was orderly and threatening (276), had the feeling that he was coming down to the pantry (283), The Secret Tabernacle (287),

("Selection" chapter) - such old wolves (293), you kept your mouth shut (294), your ankles trembled (294), the state security (298), the black cat (302), staring eyes (304), Kurt (306), make oh god a dream (310), Tabir Saraji has completely regained the former shadow (312), between the dragon and the snake (315), to share power with someone,to share crimes (318), tiger knitting, blind building (322)

(Chapter "Interpretation") - watch out for this snake (335), in those rooms only dreamers are locked 9339), brainwashing, cannibalism, madness, mind (342), with places of death (343), 
the convicts cried (346), black coffin (348), could not completely forget his dream (348), occupied the description of hell (352), I saw the state of Timur (352), a malicious dream invented against the state (353), the coffin of the dreamer (356), zaten sleep and death are the same thing (360),

(The chapter "Day of Rest" - that he understood that the Cypriots had always had work not with dreams anyway, but mainly with dreams (374), eat with us, - continued slowly, because he has the terrible power of lack of fact (375), ominous power (375) the dreamers had now turned into some snakes to bite (375), (Chapter "Archive" - six lives (388), the souls of seventy thousand white Balkans were an endless snow (395),

(Chapter "Dinner") - it was said that the Sovereign had turned back yesterday's dream (406), this had definitely related to the Palace of Dreams (417), the Vizier's Eyes had something in common with the broken glass scattered across the room (419), which Easter has to do with an epic (427), the sun has rain and the rain has sun (432),

(Chapter "The approach of spring) - had in his hand the night (447), the fatal dream (447), had taken the uncle to the grave, and him to the post of director of Tabir (447), as then he saw a coffin (450),

So,as seen in the text "harvested" and the key words consulted as such in the novel "Palace of Dreams", which help and well-orient not only his reading, but also orientation, a way to get inside the celebrities Tabir Saraj, the writer combines quite well the lexicon of popular words, composites, words created especially for such a text and context, old Albanian words and rare words.

This has helped and created the opportunity to typify and bring considerable information regarding the temporal, all-time issues of his country and its universalization. The form of the novel is a universal structure, while the internal mechanism suits the country and the issues that the writer raises for his country.

Throughout the text, in the seven chapters, the "intelligent parts" that vegetate in this text usually occupy the key paradigms of reading the book and the meanings that emerge through certain situations. A considerable number of keywords such as: - mediocre, lateral median, coffin, shestime of life, claw (tiger), bull (fierce), Oracle of Delphi, Tabir Total, Tabiri i Hidden, (pains of) gout, drunkard, liar, insomnia, raise (blind), (intermediate) state, companion, chicken (blind), snake, viper, trampler, wash (trush), center, madness, mind, are words that "float" all the text of the "Palace of Dreams".

Most of them do not come through dialogues or monologues, but in the psychological description of situations that are brought and displayed in Tabir Saraj. For example, the word middle is one of the most functional words, which is learned once Mark-Alemi has set foot in Tabir. It is the first moment when he is confronted with a scary, anonymous, mysterious structure. Mesor-e, - to be in the middle, the middle of eavesdropping, the middle of war, the middle of the field, the middle of observation. Between, as among the four roads and impossible to orient, where no one tells you where to go.

Also, the "Oracle of Delphi", which takes us to ancient antiquity, precisely in one of the most emblematic times and most metaphorically used in world art literature, a fortune-telling temple, fortune-teller, who informed and cast an opinion on fate, the wars and the futures of 
the people, leaders and peoples, which in not a few cases started wars between empires and different peoples of the time, which were included in its circle.

Another tool used by the writer is the wide range of lexical tools, with a certain symbolic, lexical, typifying and valorizing load of popular vocabulary and zoomorphology, which helps to recognize the extent of the power of the "Palace of Dreams" and the care he had to be informed, even from the province, the information that could come and through symbols like: bull, chicken, rooster, snake, viper, horse, tiger, since the story of the unraveling of dreams since time immemorial The ancients played an important role.

Not just in one case, but also in some cases the writer uses some kind of definitive communication. Vocabulary and definite structure of the type: "... many rings prevent him from holding the pen", is not simply "drawing" for one of the important taboos or only for the Sovereign. Somewhere at the end of the book the writer takes up this definition and writes: "rings can fall while the finger remains", which means despite "marriages", the ring is a symbol of marriage, the finger, the power of the "Palace of Dreams" remains. In a sense, in this case the author also says his historicism.

While in another case, which is the essence of Tabir Saraj and the historical-political allegory of the "Palace of Dreams" through the mouth of the Vizier, an authority of the imperial time, despite spending most of his time in the province, the writer notes "He eats with us," he continued slowly, "because he (Tabiri and the Palace) has the terrible power of lack of fact .."

In the climate and structure of the novel "Palace of Dreams" this is the most intelligent text that manages to explain the essence of Tabir Saraji himself. In Tabir we are informed of two deaths, which the author calls, the first black coffin and the second coffin. Both cases are related to the interception of dreamers, who in the first case are punished for not being able to completely forget his dream, and in the second case, he is likely to be accused of deliberate dreaming against the state. While the murder of rhapsodists in the house of the Vizier's family is a demonstration and a vertical connection of the way this institution works with the Sovereign. The death sentence of Kurti, a sucker of a well-known door in the Empire, is the historic extension of the preservation of power through the sowing of death and the doubts and symbolism of dreams. Tabir Saraji is his tool.

The times continue to vegetate in the novel "Palace of Dreams", not only for the convergent symbolism used by the writer, the Ottoman Empire as a time symbol, obtained from the time he established in Tabir Saraj, but also for a kind of administrative dictionary that the writer puts it in the mouths of nameless people in Tabir Saraj, because apart from the name of MarkAlem, from Tabir Saraj we are not notified by name of any of the other employees, from the front door to its top, since "Breakfast" - the first chapter of the book until "The Advent of Spring" its last chapter. Perhaps this makes the book the most up-to-date in all the countries where it has been translated and read.

"Real servant, the edges of the state, solid buildings, security of domestic policies, state security, foreign policy, social life, among all the tools of the state, I saw the state of Timurleng, the state of Herod" and other phrases, except create a temporal relationship they actualize the perception of the novel "Palace of Dreams". The novel clearly understands that it seeks a metaphor and an allegorical political approach, because in all the eavesdropping space and in all the concentration with which Tabiri, the Empire, the provinces and everything, it eavesdrops, there is only political cohesion, cohesion of power and nothing else from economy, the historical origins 
of peoples, psychological and living issues, nor humanism and issues of a sociality, regardless of the times it takes into account.

\section{Conclusions}

The novel "Palace of Dreams" is one of the prose works of the literature of socialist realism, which you wrote at a time when fiction asked to write on the model of socialist realism, which corresponded to strict ideological censorship rules, one of of which was proletarian partisanship. Despite the fact that your work was written in one of the most controlled moments of literature and everything else that was written in Albania, the novel "Palace of Dreams" managed to be published and republished in several variants, until in 1989 you were published in full in the series of works of the writer Ismail Kadare. However, the writer Ismail Kadare, after numerous refusals in various forms to intervene in the novel, in 1995 published the full novel in Paris, which was uncensored.

-The novel "Palace of Dreams" is one of the novels of the time of socialist realism, which thanks to the modern structure has managed to bring an important symbolic and allegorical communication, with a sharp social theme, which in certain forms contradicted the thematic vector and ideological of the time, in which the literary development in Albania was oriented.

- The "Palace of Dreams" in its first version is entitled "The Officer of the Palace of Dreams", and the title change in a certain space of time makes it emblematic and important to read it, as a work that to some extent viewed doubtful power and had the artistic courage to mention totalitarianism. The construction structure of Tabir Saraj in the whole complex of the novel in question has to do with a kind of typical tatality. Then the novel has a historical reflection of time, which required the reader to read the novel and in this kind of functional approach, thanks to the eternal (ether-transparent) mechanism that artistic literature has, especially the nature structures of the novel "Palace of Dreams",

- Raising you on a fantastic structure, the symbol, the construct narrated in the novel "Palace of Dreams", is a clear metaphor, which understood only in time reports. Kadare neatly used the time ratio, the time transfer and the time symbol of the Ottoman Empire for his time and the present time.

- "Palace of Dreams" is a miniature of a structure of hell, absurdity, doubt, violence, dictation, anonymity, silence, eavesdropping, suspicion, which in the complex constitute a strange labyrinth such as Tabir Saraji, mostly narrated through a the character, Mark Alemi and any other reserved and specific character, behind and within whom are the other people of the society of the time.

Anonymity, which is most evident in all the exploration of the structure, work, mechanism and tools of Tabir Saraj, is the phenomenon by which totalitarian systems display the savage eavesdropping mechanism. In Tabir no one knows the other, not spoken aloud, but also not spoken much. Every day and in every event, there are new people, unknown people, and this is the mechanism of renewed eavesdropping and severity.

Being a surreal structure, Tabir Saraji works with dreams, a phenomenon and life phenomenon of the sleeping human brain, which in contemporary critical thought has been studied and studied by psychoanalytic critique. The novel "Palace of Dreams" is a complex structure, because that within it there is a compression of times, which can be penetrated between them through the symbolism of phenomena and phenomena, which Kadare in some 
cases has taken from the universal aesthetic symbolism and most of the time has created, respecting his model.

The author has minimally used the traditional literature, ie the literature that has dealt with such an issue, reflecting what he has experienced in his contemporaries, giving the novel a kind of originality, a face, which can to be known by the people of his time, in spite of universal conventionality. The concept of a broad system that operates to conceive a certain idea, related to the content of the work, has turned the novel into a collaborative model with the reader, giving the work a social character.

Kadare has skillfully used the mechanism of form, which surprisingly has not been treated as a violation and bias of content, as in the literature of socialist realism, there has been a definite relationship between form and content. First, it seems to understood, in a surreal communication structure (mainly of the subject of dreams), that the novel in question is a "slip" from the traditionalism of the relation of form to content. This is important for the existential spirit and magical realism, which are to some extent entwined in the prose of this nature in Kadare. The symbolism of "Tabir Saraj" is complex in the novel is interpreted as a violent structure in the functional constructions of its being from the structure of hell, absurdity, mystery, violence, doubt, secrecy, murder, rape, eavesdropping, punishment and so on. Lack of fact, absurd interpretation of symbols and many other issues. Being built with a violent hierarchy, the two vaulters reflect such a dimension. -The novel "Palace of Dreams" written on a broad metaphor, easily understood when you leave the work and penetrating when entering it, mainly on the use of time, ie Ottoman time for the writer's time, for which it is necessary to understand the mechanism, understanding the transfer in time and structure of the novel.

\section{Recommendation}

The novel "Palace of Dreams", unlike traditional structures and with a classic fictions, has a mechanism to reveal it in its entirety, due to the space in which it is published, starting in the form of "Clerk...", is the character's reflection on the work and time, while in the complex version, published after the escape of totalitarianism, in 1995 from Fayard in Paris and then in Peja, the writer changed the reports and the traditional reference of the novel, sending the message to " palace". In this case, Abu Qerimi reflects on the character of Mark Alem, important enough to orient the reading of the work, as meaning through familiar symbolism cannot be easily changed.

The novel is skillfully written, making good use of linguistic styles, syntagms, knots and a rich phraseological material, which helps to discover the environments, historical-mythical stratifications, inner states of the characters, the characters of the visible characters and the possible information. Psychological to a large invisible mass, represented by Mark Alem's psychological situations and other circumstances.

- The idea of the labyrinth and the structure of Tabir Saraj is functional to understand the metaphor of the book, which has to do with the universal concept of human freedom on the one hand and the traditionally historical mechanisms of traditional totalitarianism.

- In the novel, the author uses quite well the sources- In the novel, the author uses quite well the archival sources, which he has usually used in a significant number of novels written with sharp contemporary social themes, through which the writer has enrich the golden fund of world literature. 


\section{References}

[1] History of Albanian literature, Tirana, 1978,

[2] Sinani, Shaban, "Case K", Tirana, 2001,

[3] Sinani, Shaban "The Pledge of Misunderstanding"Tirana, 1998

[4] Kuçuku, Bashkim, Kadare in languages of the world", Tirana, 2000

[5] "November "magazine, periodicals 1963-1979

[6] Newspaper "Drita", periodicals 1963-1985.

[7] Zhenet, Zherar "Figure", published by "Hejza", Rilindja, Prishtina, 1985

[8] Zhenet, Zherar "Issues of the novel", Rilindja, Prishtinë 1980,

[9] Lloshi, Xhevat "Stilystic", Tirane, 1999

[10] Mandala, Mateo: "Critical notes on the novel 'Palace of Dreams', Tirana

[11] Leka "Dictionary of literary terms", Tirana 2013,

[12] Dictionary of the Albanian language, reprints 